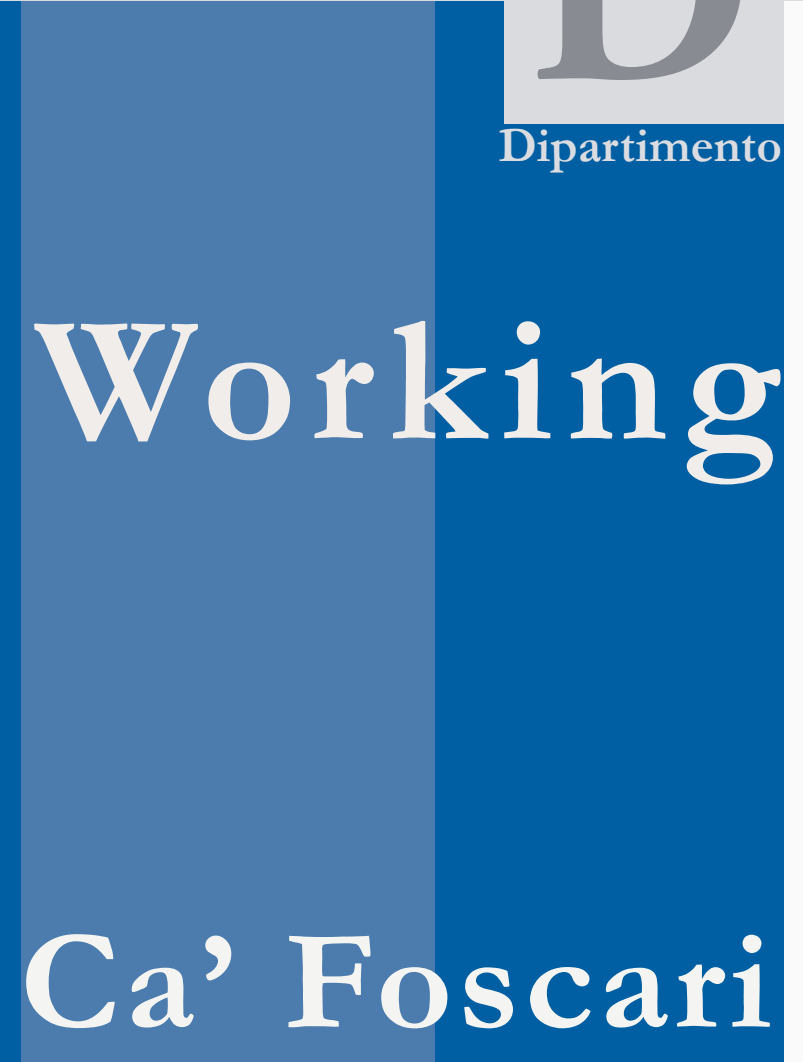

Scienze Economiche

Paper

Department

of Economics

University of

Venice

Giuseppe Tattara

The Internationalisation of Production Activities of Italian Industrial Districts 


\title{
The Internationalisation of Production Activities of Italian Industrial Districts
}

\author{
Giuseppe Tattara \\ University Ca' Foscari of Venice
}

First Draft: 2008

\begin{abstract}
This paper studies the evolution of the Italia industrial districts in the era of globalization. Italian districts are no longer self-contained systems of small firms where firms' competitiveness is the result of physical proximity, connected to foreign markets at the initial and the final stage of the production and distribution activity.

Internationalization is analysed in the three classical forms of trade flows, foreign direct investments and foreign subcontracting.

The conclusion discusses the consequences of sourcing production abroad for industrial districts. The loss of productive competences and practical knowledge, the reduction of employment and the change in the social climate that characterize the district. As a result of internationalization the final firms make profits in far away territories and the firm's profitability is no more linked to the workers well being.
\end{abstract}

\section{Keywords}

Globalization, Industrial districts, Sub-contractiong, Direct Foreign Investments

\section{JEL Codes}

F23, L16, L25, L33

to be published in:

THE HANDBOOK OF INDUSTRIAL DISTRICTS, Giacomo Becattini, Marco Bellandi and Lisa De Propris eds. Elgar.

Address for correspondence:

Giuseppe Tattara

Department of Economics

University Ca' Foscari of Venice

Cannaregio 873, Fondamenta S.Giobbe

30121 Venezia - Italy

Phone: (++39) 0412349148

Fax: (++39) 0412349176

tattara@unive.it

This Working Paper is published under the auspices of the Department of Economics of the Ca' Foscari University of Venice. Opinions expressed herein are those of the authors and not those of the Department. The Working Paper series is designed to divulge preliminary or incomplete work, circulated to favour discussion and comments. Citation of this paper should consider its provisional character.

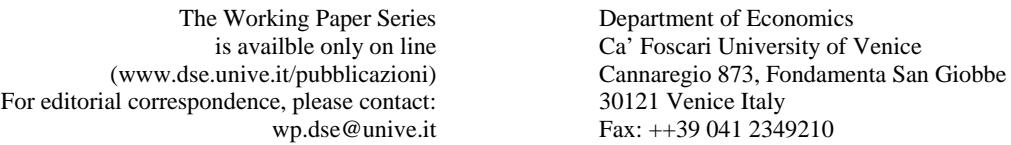




\section{The Internationalisation of Production Activities of Italian Industrial Districts ${ }^{1}$}

\section{Introduction}

Industrial districts, since the seventies, have been the engines of Italian industrial growth and of the rapid increase in Italian manufacturing exports. The districts have developed in particular in the Made in Italy $^{2}$ and mechanical engineering sectors (Becattini 1995-96; Becattini, Menghinello 1998). The Italian economy being poor in raw materials, manufacturing activity developed as an industrial process that transformed imported goods. Consequently, the Italian districts are big importers of raw materials and exporters of finished goods, i.e. they are connected abroad through large flows of imports and exports (Becattini, 1995-96; Brusco and Paba, 1996; Piore and Sabel 1984; Foresti, Trenti, 2006). Few districts, if any, are dependent on domestic demand.

Globalization has brought about a sharp increase in the real and financial integration of the worldwide economy and the structure of the Italian districts has evolved in parallel. Italian districts are no longer self-contained systems of small firms where firms' competitiveness is the result of physical proximity, connected to foreign markets at the initial and the final stage of the production and distribution activity. In the new context, firms often expand or transfer abroad one or more phases of their production activities. Thus production abroad has become the focus of industrial strategies followed by district firms seeking to reduce costs and/or to exploit potential new markets.

Globalization has reshaped the form of the district. Most district firms are now organizing their value chains by coupling district knowledge and competencies (Becattini and Rullani, 1992) with opportunities offered by the globalization processes. It is often the complementarity between the location-bound 'strengths' of domestic components and the non location-bound knowledge of the foreign components that leads to valuable new resource combinations. For example, foreign multinational enterprises setting up production in a district may provide access to assets, skills and routines that may usefully complement the location-bound knowledge of domestic firms. At the same time, foreign firms have access to important knowledge relations. The rise of integration at the international level has contributed to the transformation of industrial districts and in some cases has proved to be the real driver of a district firm's competitiveness in recent years (Di Maria and Micelli, 2007).

In the post World War II economy, the shift of manufacturing towards countries with low labour costs began, according to some scholars, at the beginning of the $70 \mathrm{~s},{ }^{3}$ and at first involved countries with high labour costs such as the USA, Germany, Sweden,

\footnotetext{
${ }^{1}$ I would like to thanks Renzo Bianchi and Frank Pyke for their helpful suggestions.

${ }^{2}$ The "Made in Italy" sector refers to clothing-footwear-fashion, furnishing-house and food-wines

${ }^{3}$ For brevity we do not take into account the numerous historical experiences of de-localization. For an account, see Findlay, O’Rourke (2003).
} 
Denmark, and the U.K. (Ádám, 1971; Finger 1976; 1977). Italy and Spain entered the process much later in the early nineties, in response to the increased competition from firms that had already outsourced to low cost countries, and in the context of a more liberal international setting. Italian firms were induced to outsource by the opening up of the Central-East European countries, while the decision by Italy to join the euro zone has prevented a familiar recourse to currency devaluations, a policy that previously periodically readjusted the competitive power of Italian exporters.

Additionally, the participation of East European countries, including Russia, as well as India and China, in the international consumption market, with their high rates of growth in a world developing at low speed, has provided a further incentive to transfer manufacturing production abroad by locating outposts in areas close to markets with high sales potential.

Although many economists associate internationalization (especially exporting and foreign direct investment) with size, the district firm is typically small. In fact, the relation between size and the various forms of internationalization is rather uncertain in a production context where network relations prevail. The firm's size, traditionally measured by the number of employees, is an ambiguous measure of its level of activity. Firms in the district, in many cases, do not grow in size because they follow alternative strategies - such as relying externally on particular production phases, being part of formal and informal collaborative groups, and establishing informal connections with other firms in the district - and these phenomena are not adequately accounted for in the available statistics. Final production and exports from districts emerge from informal networks that stay invisible to the usual statistical measures. At the same time, the fragmented production structure of the district turns out to be an advantage in sourcing from abroad as, in many circumstances, such sourcing means in fact simply transferring production phases that already exist in the local territory. This process can develop through foreign direct investments, but in most cases it is through simple subcontracting, frequently transferring to a foreign context sourcing from enterprises that use the same types of machines that were previously employed in the district, or pushing former sub-contractors to establish their plants abroad in order to reduce costs a common practice for the Italian clothing and footwear districts sourcing from Eastern Europe.

The way district networks are organized affects the degree of internationalization. Lazerson and Lorenzoni (1999) and Tattara (2001) suggest an important role for lead firms in developing districts, and according to Lazerson and Lorenzoni those districts with a strong presence of lead firms are the most inclined to international success. Lead firms, generally firms of medium size, organize much of the activity of a district - for example, concerning the development of technologies, skills and knowledge generation and dispersion , the seeking out of new markets, and the management and organization of efficient value chains at the international level through foreign direct investments and sub-contracting ${ }^{4}$.

Porter and his followers emphasise the importance of domestic rivalry as a prerequisite for successful internationalization (Porter, 1990 and 1998; Sakakibara and Porter, 2001). According to Porter, domestic rivalry pressurises firms to innovate and upgrade while fostering positive externalities in the local business environment, such as supplier availability, easier access to technology, market information, and specialized human

\footnotetext{
${ }^{4}$ Rugman and Verbeke (2005) speculate that asymmetric clusters, i.e. clusters with the presence of leading firms, are more oriented to success in the international market.
} 
resource development. Excessive horizontal and vertical concentration reduces domestic rivalry, generates inefficiencies and local sub-contractors are transformed into passive agents of a static player, rather than being actors able to face successfully the international competitive market.

The scenario for most of the Italian districts is one of a presence of several mediumsized lead firms, operating in closely related niche markets, linked by elements of collaboration and rivalry that create strong competitive incentives together with greater pressure to upgrade production, an idea that goes back to Schumpeter (1911) who saw competition as a dynamic process of creating new products and processes. Dynamic competition spurs innovation and production improvement and in turn international competitiveness.

\section{Production Internationalization}

District firms establish relations with actors in foreign countries through a multiplicity of channels: through import and export trade flows; through direct investments abroad and from abroad; through sub-contracting; and through commercial, technological and other kinds of formal and informal agreements.

A significant part of firms' overseas activities involves the use of intermediary forms of internationalisation in the shape of trade agreements and sub-contracting, both of which are particularly important in the case of Italian small and medium size firms (Bigarelli, Ginzburg, 2005; Capitalia, 2005). These "light” forms involve less capital flows compared to foreign direct investments, but greater commodity flows, as commodities are sent abroad in order to be processed and be subsequently re-imported. However, such commodity flows are not separately recorded from the general transit of goods passing through the Customs, and therefore are difficult to identify. Because of this, and not because such light intermediary forms are unimportant, international trade experts have not really taken them into serious consideration (Bugamelli, Cipollone and Infante, 2000). Yet empirical evidence shows that internationalisation in the form of direct investment involves a limited number of businesses; much more many firms have engaged in intermediary forms, such as technical collaboration agreements with overseas companies.

In Italy, the little analysis available seems to indicate that the traditional sectors, and those sectors characterised by important economies of scale, are less present in overseas markets and hold smaller foreign direct investments than do the high-tech sectors. This conclusion contrasts with anecdotal evidence which indicates that in Italy the delocalization of the textiles, clothing and footwear sectors is highly significant (CEPS, 2005; Rossetti, Schiattarella, 2003; Constantin, De Giusti, Tattara, 2008), but occurs in the light forms mentioned earlier. For example, within traditional sectors there has been a steady and substantial increase in the number of firms that have established trade agreements with overseas partners (Bugamelli, Cipollone and Infante, 2000). Also, a large study of Italian manufacturing sectors with more than ten employees, for the period 2000-2003, revealed the well known fact that the large majority of Italian firms export abroad (70 percent of the total), and that the majority of them were maintaining, 
or starting up, trade operations or overseas trade agreements with foreign correspondents, with a marked increase over earlier periods (Capitalia, 2005

\subsection{Trade Flows}

Trade is the most well known form of internationalization. Studies on the export performance of Italian districts have aimed to provide empirical evidence that district firms have a better export performance than non-district firms. A first difficulty encountered in analysis has been the matching up of trade statistics with the district spatial form ${ }^{5}$. Trade statistics are seldom available for circumscribed territorial units, like the districts. Empirical analysis by Bronzini (2000) relied on using "local labour systems" ${ }^{\prime 6}$ to collect relevant statistical information for districts. From this it was possible to define an index of district intensity for each province ${ }^{7}$ and then the export performance of the various provinces could be related to the relative district intensity. If provincial exports proved to be dynamic in the provinces with a high degree of districtualisation, it was possible to infer that the districts were at the root of the positive export performance. In fact, according to Bronzini, Italian districts presented a strong export performance compared with the national average, and some of the most dynamic export areas were typically districts (Bronzini, 2000).

Menghinello (2003), and De Propris, Menghinello, and Sugden (2008) have more recently taken up the challenge. They provide more up to date statistics, and demonstrate that industrial districts are among the most competitive of local industrial systems, and De Propris et al. show that the districts account for a remarkable share of national exports across different sectors, thus disproving the traditional view of a sector-specific effect on the Italian economy.

The positive relation between districts and exports has several possible explanations. The positive role of the Marshallian district economies on exports is specifically tested by Bronzini (2000) and looks significant, even when controlling for sectors, size and infrastructures Interestingly, the author shows that the positive role of the size variable on exports, for firms located out of the district, is 'equalled' by the territorial agglomeration variable for smaller district firms; economies of scale in the provision of export services and informal face-to-face exchanges of information about export markets may improve the export performance of small firms in the district.

Becchetti, De Panizza and Oropallo (2007) tackle the problem of the relation between districts and exports with the help of a more sophisticated database. They study the export, and value-added, performances of industrial districts by integrating information on the population of Italian firms (from the ASIA database of the Italian Statistical Institute) with balance sheet data for all limited liability companies in selected manufacturing industries. The findings show that firms located in industrial districts export more, and have higher value added, than firms located elsewhere, net of the impact of appropriate controls.

De Arcangelis and Ferri (2005) provide a new insight into the export dynamics of the Italian districts. They advance the idea that the specialization of the Italian industrial districts has changed over time, since the nineties, and many districts are now

\footnotetext{
${ }^{5}$ This point is carefully analysed by Menghinello, forthcoming, the Handbook of industrial districts.

${ }^{6}$ See chapter.....the Handbook of industrial districts, forthcoming.

${ }^{7}$ Menghinello, , forthcoming, the Handbook of industrial districts.
} 
specializing in the production of capital goods directly linked with the districts' traditional areas of specialization, mainly exemplified by Made in Italy consumption goods. The same line of argument is advanced by Russo with relation to the tile district of Sassuolo (2006) in respect of a shift towards the production of tile making machines; and also by De Giusti (2006) who points out the increase of exports of machines used in clothing and shoe making abroad, consequent upon an increase of sourcing from abroad in those sectors by the firms of the Veneto districts. These researches reopen the question posed long ago by Becattini (1979) about the usefulness of defining district specialization with reference to the entire, vertically integrated, manufacturing process (filière), and also draws attention to the ambiguity of measures of district export propensity defined only on the basis of the final product without considering capital goods.

A filière approach would require a new definition of the district that embeds the manufacturers of capital goods linked to a district specialization. But the link is not a straightforward one. In many cases machine manufacturers inhabit a territory that stretches beyond district borders and so the significance of proximity might need to be rethought.

For machine manufacturers there is little tendency to agglomerate with the downstream users of their machines.

Machine manufacturers have similarities in that they all have a capacity to operate with both mechanical and electronic processes, and face common specific problems related to metal technology (such as in respect of friction reduction, the various properties of metals and the use of electronic controls), but they are limited in number and serve customers located in a wide area (Rosenberg, 1963a, pg. 219). In few situations are machine producers located in proximity to final downstream users of their machines (Rosenberg, 1963b, pg. 423), and so the concept of filiere, in such circumstances, is not necessarily a concept of territorial proximity.

\section{2 Foreign Direct Investment}

Foreign direct investment is an important tool of production internationalization for medium and large-sized firms. Foreign direct investment is an investment realised abroad (outward investment) or from abroad (inward investment) and can take place either through the opening of branch plants (green field investment) or through financial participation in existing firms (brown field investment). The motive behind the investment from the perspective of the investing firm is resource seeking, if the firm aims at accessing cheap labour and/or natural resources, or market seeking, if the firm aims at either penetrating new markets or maintaining existing ones.

The large direct investments of the past by the UK and later on by the USA were mainly directed at exploiting natural resources, while today integration at the international level has stressed the capacity of low cost countries to perform significant phases of manufacturing production. In this context, district firms have been sourcing specific production phases in that process abroad; at the same time, their high level of performance has attracted foreign investors that want to "breathe" the district air ${ }^{8}$.

\footnotetext{
${ }^{8}$ The creation of the foreign direct investment data-base in Italy is the result of careful work directed by Cominotti and Mariotti at the Polytechnic of Milan (1994). Their database reports detailed information on foreign ownership for all manufacturing firms located in Italy, and foreign-owned manufacturing firms
} 
A study by De Propris and Menghinello (2005) employs an inward direct investment database stratified by industry and province to show that the specific properties of territorial agglomeration are an important explanatory variable of inward investment flows. Industrial districts are attractive to foreign direct investments which enter the locality and become part of the local networks; foreign firms look to benefit from gaining access to a district's specialization and seek to be embedded in its governance structure.

Harrison, in a more descriptive and less systematic way, provides anecdotal analysis of inward investments into the Italian region of Emilia-Romagna, mainly brown-field, by foreign firms wishing to enter the more successful Italian districts (Harrison, 1994).

Big multinationals have entered the Italian districts in order to augment their knowledge base through obtaining access to foreign pools of knowledge, i.e., by becoming participants in various localized knowledge clusters. Cases in point include the acquisition in the Montebelluna district of Canstar by Nike (subsequently sold, the direct investment being substituted by a permanent sub-contracting relation); the acquisition of Calzaturificio Monique, a leader in the lady's footwear district Riviera del Brenta, by Louis Vuitton; the purchase of Marelli Motori and Lowara, two of the most important producers of the electric motor district of Vicenza, by FKI energy technology and by ITT respectively; and many others. The number of inward foreign direct investments in Italy has recently rapidly increased and if globalization has diminished many of the traditional roles of location, districts seem to be able to exert a growing importance as attractors in an increasingly complex, knowledge-based and dynamic economy.

Much more debated by Italian researchers is the issue of outward investments. Using data from Ufficio Italiano dei Cambi, Federico (2006) analyses for the period 19972001 the distribution of foreign direct investment outflows by sector and local area of origin and investigates which industrial location has a larger propensity to invest abroad. Controlling for a set of variables, the author does not find any evidence that the presence of districts has a positive impact on foreign direct investments, contrary to what happens for exports. Foreign direct investment outflows are mainly generated from firms in the two metropolitan centres of Milan and Turin where larger size firms are located. Additionally, foreign direct investments are more frequent for firms producing capital intensive goods, and those goods are not typical of district production. The explanation of the weak role played by industrial districts in outward foreign direct investments is attributed by the author to sunk costs connected with the decision to invest abroad and to the fact that smaller firms make more recourse to light forms of internationalisation, mainly sub-contracting and informal agreements. Thus the little direct investment is explained by the large amount outsourced in other forms. The amount of foreign direct investment is not a correct indicator of internationalisation for those small and medium- sized firms which make recourse to sub-contracting, nor for international brand names and retailers that lead consumer - driven value chains, providing designs, supervising quality and the delivery of products from abroad (Gereffi,1993; Gereffi, Humphrey, Sturgeon 2005).

Although Italian districts do not emerge as the generating core of foreign direct investments, foreign investments from the districts have a home impact and the structure of the domestic value chain is consequently affected. Maggi, Mariotti and

located abroad and owned by Italian entrepreneurs with a turnover superior to 2,5 million euros. On the recent statistics provided by the Italian Central Statistical Office, see Menghinello, this volume. 
Boscacci (2007) have studied the effect of foreign direct investment from district firms of the Italian North East (34 districts in the Made in Italy and electro-mechanical sectors) on local value chain organization. They find that the internationalisation of production phases leads to a more expensive and complex logistics system, requiring more supervision, coordination and control over geographically dispersed activities.

\section{3 . Sub-contracting}

Small and medium- sized firms extend their supply chain abroad through international strategic alliances that can take various forms (Dunning, 2001). The most common form of outsourcing is a non-equity agreement between a firm and one or more of its suppliers to act as sub-contractors, supplying, producing or distributing the firm's products. Sub-contracting does not involve separate venture or equity investments and is less formal than equity relations.

The incentive to hire sub-contractors is either to reduce costs or to mitigate project risks. Through such means, the general contractor receives the same or better service than he could have provided by himself, at lower overall risk since one of the main aims of subcontracting is an increased flexibility in the supply chain. Many sub-contractors work regularly for the same customers, allowing them thereby to develop specialized competences.

Sourcing abroad through sub-contracting is one of the most common ways of opening up the value chain beyond the industrial district. If in the past it was mainly the case that goods and services were domestically accessible, in the nearby territory, now district firms have started to look beyond the district borders, sourcing production phases in countries with low labour costs. In those industrial districts where a decomposition of production phases is common practice, sourcing from abroad is relatively straightforward, and small firms, having limited finances, make recourse to subcontracting. For example, many firms operating in the clothing districts have developed growing sub-contracting relations with firms located in South-East Asia, in Central-East Europe and in North Africa, while numerous firms in footwear districts have looked mainly to Central-East Europe and East Asia.

Italian districts also contain firms which are part of international chains whose head offices are located abroad and which source significant phases of production from within the districts. Rather well known examples of such districts include the plastic moulds district (Montebelluna-Oderzo) that supplies the international automotive industry; the Livenza furniture district which is, in Europe, a large supplier of Ikea; the jewellery district in Vicenza that supplies watch cases to large international watchmakers; and the lady's footwear district of Riviera del Brenta that supplies high fashion international brands such as Vuitton, Dior, Jimmy Chow and others.

Due to low transport costs and the use of information technology, sub-contracting is profitable even if production lots are small (say hundreds of pieces of clothing, not thousands) and products vary considerably in kind. Sub-contracting is accompanied by a process of standardization and codifiability, although face-to-face relations prove still to be very important, particularly for complex products. Foreign direct investments are prevalent when production quantities are large, where a hierarchical organization is more suitable and where fiscal conditions in the country of investment are favourable.

Successful sub-contracting requires action by governments, as it benefits from a specific tariff provision. The Outward Processing Trade provision of the EU and the preferential 
tariff treatment envisaged by the Trade and Development Act for the USA in respect to the Caribbean are examples. Those transactions which make recourse to the Outward Processing Trade provision are largely concentrated in sectors characterized as labourintensive -- textiles and clothing, footwear, some categories of machinery and mechanical appliances, other industrial goods, vehicles, processed food and leather products. Textiles and clothing exports are an important source of export earnings for the East European countries.

Full package sourcing, where suppliers take on the responsibility of delivering a complete product, is practised in countries with raw material availability and a long experience in manufacturing, as is the case, for example, in South Asian countries (Gereffi, 2002). Full package sub-contracting is often accompanied by the establishment abroad of distribution and commercialization phases, and is referred to as horizontal sub-contracting.

Recent sub-contracting flows show that a lot of outsourcing work is taken up by small and medium- sized firms and, in the case of Italy, much is also originated by small and medium- sized firms. The trade flows of merchandise related to outsourcing are very unstable due to the absence of sunk costs (which are in fact a characteristic of the foreign direct investment process). There are costs in changing contractors, of course, related to the need to build up commitment and trust; episodic relationships do not guarantee quality and time to market.

When Portugal joined the EU in 1986, and during the transition period to membership, Portugal attracted a lot of outward processing trade. When the low labour cost attraction weakened or disappeared, the EU's outward processing operations shifted to North Africa, Turkey and Yugoslavia, and later to Eastern Europe. By the early 1990s employment and output were falling in Portugal, particularly because German retailers switched orders to Eastern Europe. Exports from Portugal to Germany fell sharply and clothing employment in Portugal declined by almost 25 per cent between 1991 and 1995 (Thiel et al., 2000). The same happened subsequently with Poland and there are signs that the same process is now affecting Romania..

International sub-contracting can take different forms. In one form, known as industrial sub-contracting, only some production phases, frequently the most highly labour intensive ones, are transferred abroad. The product is re-imported at some stage in order to perform final assembly and finishing. In the case of Made in Italy goods, this process can guarantee a legitimate use of the Made in Italy label.

The way relations with foreign suppliers is organised reflects numerous elements, including transport costs, product codifications, the confidentiality of customer-supplier relations, and the levels of technology in the supplying country. In Eastern Europe and North Africa, raw materials of high quality are seldom available and so it is necessary for the outsourcing firm to send them for processing. The technological infrastructure is often discontinuous and some production phases are unavailable. Modern production requires complex processing phases in all sectors, in traditional as well as in more advanced production. For example, Italian clothing, footwear and furniture firms sourcing in Romania have faced bottlenecks in fabric printing and dying, sole ignition, and trivalent chrome plating respectively. In order to complete the production phases abroad the "governance" of the value chain has intervened, either directly through direct investments or inducing third parties to make new investments (Constantin, De Giusti, Tattara, 2008). Only by producing a coherent sequence of production phases 
abroad $^{9}$ is such sourcing made profitable, and in many cases both sub-contracting and direct investments are used to remove the bottlenecks in the production chain.

Both vertical and horizontal sub-contracting relations are difficult to measure from available statistics. Ideally, what is required is a measure of intra-industry flows. As things stand, intra-industry trade can refer both to sub-contracting and foreign direct investments, and it is made up of intermediate imports and exports as well as those of final products. Full package sub-contracting and foreign direct investments generate trade flows that are indistinguishable from exports and imports of finished products of foreign origin, and it is very difficult to disentangle the complex trade relations and estimate what proportion of trade is due to foreign sourcing ${ }^{10}$.

A large part of the increments registered in trade values at the world level in most recent years is due to trade in intermediate products (Yeats,1998; Kaminski, Ng, 2000) and this has been related to the practice of external sourcing, but, of course, not all intermediate flows are intra-industry flows. The stages of production and countries involved must be carefully considered in order to avoid misleading conclusions.

For some countries outward processing imports and exports are separately counted, but statistics are often unreliable (within a single production organization values are basically 'transfer prices') and firms make recourse to the outward processing tariff procedure only if tariffs are significant, but not if there are quotas or other impediments to trade (Tattara, Corò, Volpe, 2006).

\section{The Effects of Sourcing Abroad on Enterprise Performance and Employment}

Studies aiming to discuss the impact of internationalisation need to take into account all of the various internationalization strategies, including foreign direct investments and sub-contracting, and the various other forms of agreements. Assuming (majority) equity investment as a proxy for production outsourcing blurs the analysis as foreign direct investment is only part of a larger set of decisions: sometimes direct investment acts to complement and sometimes to substitute for other forms of sourcing, and cannot be meaningfully analysed in isolation.

Rossetti and Schiattarella (2003) examined Italian sourcing abroad in the Made in Italy sectors looking at trade flows, following the approach pioneered by Yeats (1998) and Kaminsky and $\mathrm{Ng}$ (2000). The quantitative measure of intermediate trade flows for different regions, carefully scrutinized at the commodity level, is related to an estimate of employment activated abroad and to the possible employment change at home. The encouraging result is that while sourcing from abroad in the nineties grew rapidly, Italian outsourcing regions increased their home employment and labour income per labour unit rose.

\footnotetext{
${ }^{9}$ According to Dahmén (1989), economic success in certain processes may require the realization of one or more specific complementary processes or stages and such complementarities appear in many different forms as important elements of the process dynamics. Part of a process can be completed by a single entrepreneur or group of entrepreneurs..."the aim is making products and services salable by initiatives to find new technical solutions, and to invest, or make others invest, in other sectors of the economy" (p. 113)

${ }^{10}$ The problem of disentangling intra-industry trade into horizontal and vertical elements is the object of several studies. See, among others, Al-Mawali (2005) and Fontagné, Freudenberg, Gaulier (2005). An attempt to connect the problem of vertical intra-industry trade with district specialization is in Corò, Volpe (2006).
} 
A study by Gianelle and Tattara (2008) aimed at assessing the impact of outsourcing on district firms' performance, taking into account various forms of sourcing from abroad. Direct investments, sub-contracting and partnerships that result in increased production abroad are jointly considered, with information coming from a survey delivered to a group of 70 finalproducers, operating in the clothing and footwear districts of the Veneto, which during the 90s began to manage production on a global scale. The research was based on an ad hoc database that takes into account the above mentioned survey on production manufactured abroad in relation to turnover, data on employment at the firm level and information from the firm's balance sheets during the years 19902003.

In Eastern Europe, in clothing and footwear in particular, the management of value chains based on sub-contracting prevail over those based on direct investment because of the relatively simple processes which can be carried out abroad, low transport costs and the skills available in many of these countries. Small and medium Italian manufacturers in traditional sectors are not able (from an organisational and financial point of view) to undertake complex operations, and few of them have made direct investments in overseas markets, but the majority have created a dense network of subcontracting relations with foreign companies in order to manufacture segments of the value chain under their surveillance and at a low cost.

Is it possible to estimate the impact of organising production in a global value chain framework, with significant sourcing from abroad, on a firm's turnover and gross earnings? In Gianelle and Tattara's study, the conclusiont is that sourcing from abroad has a net positive impact on profits and turnover; however the positive effect is a once only event and is not followed by a large rate of growth through time: it disappears when the movement towards foreign production is completed. The rationale for this conclusion is that outsourcing, in the majority of cases, occurs with the transfer abroad of phases and processes previously carried out in Italy, encouraged by increased price competition at the international level, while the machinery and the production techniques remain substantially unchanged. In order to continue in a positive vein a sequence of governance innovations (such as the introduction of product modularisation, or an export of knowledge) is required that is liable to further increase productivity and encourage the use of new technologies.

Working in an increasingly complex international setting encourages final producers to improve managerial and organisational efficiency and increases domestic demand for skilled high value added services ${ }^{11}$. Nonetheless, the choice to de-localize abroad has an immediate strong negative impact on employment in small artisan workshops and on the connected skills, particularly in a region where the number of people employed in manufacturing is high, as in the Veneto in clothing and footwear, and where domestic sourcing was common practice in the eighties, just before the onset of foreign sourcing (Gianelle and Tattara 2008). The negative consequences of the drastic reduction in domestic sourcing, and the crisis of some big brands that have not been able to manage the value chain at an international level, is evident.

The impact of outward foreign direct investment on domestic employment is negative in the case of vertical investment undertaken - especially by smaller firms - in less developed countries, and positive for horizontal and market-seeking investments in

\footnotetext{
11 Gereffi (1999) stresses that being part of a value chain at an international level helps enterprises acquire knowledge and therefore a significant opportunity for production upgrading.
} 
advanced countries (Barba, Navaretti, Castellani and Disdier, 2006). The first kind of investment points to a substitution, while the second points to an enlargement of firm activity towards new markets and a positive overall effect on domestic employment, basically due to the extension of functions provided by the lead company in order to manage more complex networks. In many circumstances both motives are present, and the sum outcomes of the vertical and horizontal functions of the foreign investment are uncertain. This is often the case for sourcing from East Asia, with a view to the large markets of China and India, and also from Central-East Europe, considered a gateway to the rapidly growing Russian market.

Sourcing from abroad makes the management of value chains more complex and so a positive correlation might be expected between internationalization and employment growth in the logistics sector ${ }^{12}$. There is limited evidence that in the case of the Montebelluna district (Maggi, Mariotti and Boscacci, 2007) logistics is mainly sourced locally by the final producer, and if so it would be useful to examine employment growth and changes in skills requirements within the individual firm and/or within the district. Of course, the logistics activities of district firms could alternatively be supplied by third party logistics providers located outside the districts, or by players located in foreign markets, or in the market where the foreign investment has been made. There is aggregated evidence that Italian firms are buying abroad more logistics services than they sell, and the Italian balance of payment in logistics services is heavily negative

\section{Conclusions}

A reduction in transport costs, a liberal environment, and the intensification of trade has allowed firms to extend their competitive advantages across district borders. At the local level, the increase of various forms of internationalization has generated both centrifugal forces inducing exits from the local districts to grab new opportunities arising in the growing international market, and centripetal forces as in-comers are attracted by possible competitive advantages rooted in membership of a local community (Leamer, Storper, 2001).

A massive and rapid outsourcing of production activities from districts can lead to an impoverishment of old production areas, not only in terms of employment but also in respect of knowledge and skills. The innovations that have been at the root of the 'Made in Italy' success have nearly always developed out of very close contacts between people that design and people that make. In the district, product and process innovations arise from the production context and come out of the daily familiar use of machines and production materials: producing an integration between tacit and codified knowledge (ch.6 this handbook?). If the industrial districts lose their production competences do they run the risk of losing also their competitive advantage in designing successful products? Can a favourable scenario be reasonably assumed where Italy maintains within its own borders the higher value added stages, such as marketing, design and logistics, while realizing in other countries the more labour intensive and less skill intensive components? The question has a solid ground because some entrepreneurs have demonstrated increasing difficulties in finding in Italy workers with the necessary skills and knowledge, and this is a clear indication that the local pool of competences, from which the enterprises have drawn in the past, is today being diluted.

\footnotetext{
${ }^{12}$ On the causal relation between foreign direct investments and services, Nefussi, Schwellnus (2007)
} 
On the other hand, firms need highly qualified people, with new kinds of competences, to assist their delocalisation process abroad.

In some cases, several branded district firms - of medium size - have reinforced their leading roles and proved able to manage the global value chain. This has brought into being a complex management process, involving, on the one hand, cooperation with highly qualified partners, in the district and abroad, for the purposes of product development and, on other hand, arm-length relations with other foreign contractors, that have to comply with the branded firm's requirements at low cost and without delay. Foreign sub-contractors of this kind are mainly engaged in simple assembly, dependent on the lead firm for raw materials and components and are easily substituted when labour costs in the country where they are located start growing ${ }^{13}$.

Internationalization has consequences that can affect the basic social principles that ground the nature and the climate of the Italian industrial districts, including their capacities to regenerate in locally coherent forms work, culture, social relations, and material and immaterial infrastructures that construct the district identity (Becattini and Rullani, 1992). In the district, a large part of the process of knowledge transmission has been historically based on the interconnections between economic-production conditions and socio-cultural reproductive conditions of the social system. Moreover, in the district area a mutual solidarity has connected small firm entrepreneurs, territory and society towards the attainment of a mutual progress: the destiny of the firm has often been considered in symbiosis with that of the workers.

Over the last decade, the firms of the Italian Made in Italy districts are leading their way along a different trend. Profit realization is now further and further away from places where companies that lead the production chains are located. Therefore, a positive profit by the final producers no longer directly reflects positive corresponding variations in local employment and in local revenues and this inevitably corrodes some of the constituent characters of the industrial districts.

\footnotetext{
${ }^{13}$ In the case of those Italian districts producing for top brand value chains at the world level the result may be the opposite: according to Rabellotti (2006) several Italian firms complained of suffering from functional downgrading and a loss of their direct link to the market.
} 


\section{References}

Ádám, G. (1971), 'New trends in international business: worldwide sourcing and domiciling’, Acta Oeconomica, 7 (3-4), pp.349-367.

Barba Navaretti Giorgio, Castellani Davide and Disdier Anne-Célia (2006), How does Investing in Cheap Labour Countries Affect Performance at Home? France and Italy. Centro Studi Luca d’Agliano, Development Studies Working Papers, n. 215

Becattini Giacomo, Menghinello Stefano (1998), Contributo e ruolo del made in Italy distrettuale nelle esportazioni nazionali di manufatti. Sviluppo locale 9:(1) , pp. 5-41

Becattini Giacomo, Rullani Enzo (1992), Global Systems and Local Systems. In Industrial Districts and Local Economic Regeneration by Frank Pyke (Editor), Werner Sengenberger (Editor). International Labour Org.

Becattini Giacomo. 1979. Dal 'settore' industriale al 'distretto' industriale. Alcune considerazioni sull'unità di indagine dell'economia industriale. Rivista di economia e politica industriale 1, pp. 7-14. Reprint in: 1987. Mercato e forze locali: il distretto industriale, Giacomo Becattini ed. Bologna: il Mulino.

Becattini Giacomo. 1995-96. I sistemi locali nello sviluppo economico italiano e nella sua interpretazione. Sviluppo locale 2-3: pp. 5-25.

Becchetti Leonardo, Da Panizza Andrea, Oropallo Filippo Role of Industrial Districts Externalities in Export and Value -added Performance: Evidence from the Population of Italian Firms, Regional Studies 41(5), pp. 601-621.

Bigarelli Daniela, Ginzburg Andrea, 2005, Gruppi di impresa e processi di internazionalizzazione nelle Pmi in provincia di Reggio Emilia, Economia e Società Regionale, Fascicolo 4(92), pp. 5-29.

Bronzini Raffaello (2007), FDI Inflows, Agglomeration and Host country Firms'Size: Evidence from Italy. Regional Studies, v.41(7), pp. 963-978.

Brusco Sebastiano, Sergio Paba (1997). Per una storia dei distretti industriali italiano dal secondo dopoguerra agli anni novanta. In Storia del capitalismo italiano dal dopoguerra ad oggi, Fabrizio Barca (ed.). Roma: Donzelli, pp. 265-333.

Bugamelli Matteo , Cipollone Piero, Infante Luigi (2000), L’internazionalizzazione delle imprese italiane negli anni novanta, in Rivista italiana degli economisti, n. 3, pp. 349-386.

Capitalia, 2005, Indagine sulle imprese italiane.Rapporto sul sistema produttivo e la politica industriale. Osservatorio sulle piccole imprese. Ottobre.

Ceps (Centre for European olicy studies), WIIW (Winer Institut für Internazionale Wirschaftgeshichte) (2005) Final Report. Part1: The Textile and Clothing Industries in an Enlarged Community and the Outlook in the Candidate States, 
$<$ www.europa.eu.int/comm/enterprise/textile/documents/tc_study_jan2005_new_ms_bg ro.pdf $>$

Cominotti Ruggero, Mariotti Sergio (eds.) (1994) Italia multinazionale 1994. Le nuove frontiere dell'internazionalizzazione produttiva, Etas Libri, Milano.

Constantin Florentina, De Giusti Giovanna, Tattara Giuseppe, 2008, Processi di internazionalizzazione nei distretti del Nord-Est, WP DSE. University of Venice.

Corò Giancarlo, Volpe Mario (2006) Apertura internazionale della produzione nei distretti italiani. In Giuseppe Tattara, Giancarlo Corò and Mario Volpe (eds.), Andarsene per continuare a crescere.

Dahmén Erik (1989) 'Development blocks' in industrial economics. In Bo Carlsson (ed.) Industrial Dynamics, Kluwer. MA, pp. 109-121.

De Arcangelis Giuseppe, Ferri Giovanni (2005) La specializzazione dei distretti: dai beni finali ai macchinari del Made in Italy? In Sognorini Luigi F., Omiccioli Massimo (eds.), Economie locali e competizione globale, Il Mulino, Bologna, pp. 283-297.

De Giusti Giovanna, (2006) Processi di inetrnazionalizzazione nel distretto liventino del mobile moderno. Alcuni casi di studio. Tesi di laurea. Università di Ca Foscari, Venezia, aa. 2005-2006.

De Propris Lisa Nigel L. Driffield, Menghinello Stefano (2005) Local industrial systems and the location of FDI in Italy, International Journal of the Economics of Business, 12,1, pp. 105-121

De Propris, Lisa, Menghinello, Stefano, Sugden, R. (forthcoming 2008) “The Internationalisation of Local Production Systems: Embeddedness, Openness and Governance”, Entrepreneurship and regional development. In print

Di Maria Eleonora, Micelli Stefano (2007) District leaders as open networks: emerging business strategies in Italian industrial districts. Working Papers Dipartimento di Scienze Economiche "Marco Fanno".n.0038.

Dunning John.H. (2001) The Eclectic (OLI) Paradigm of International Production, International Journal of Economico and Business, vol.8 n.2, pp. 173-90

Federico Stefano (2006) L’internazionalizzazione produttiva italiana e I distretti industriali: un'analisi degli investimenti diretti all'estero. Servizio studi, Banca d'Italia. Temi di discussione, n. 592 may.

Findlay Ronald, O'Rourke Kevin H.(2003) Commodity Market Integration, 1500-2000. Globalization in historical perspective, pp. 13-62, NBER Conference Report series. Chicago and London: University of Chicago Press

Finger, J. Michael (1977) Offshore Assembly Provision in the West German and Netherlands Tariffs: Trade and Domestic Effects, Weltwirtschaftliches Archiv, 113 (2), pp. 237-249.

Finger, J. Michael (1976) Trade and domestic effects of offshore assembly provision in the U.S. tariff, The American Economic Review, 66 (4), pp.598-611.

Fontagné Lionel, Freudenberg Michael, Gaulier Guillaume (2005) Disentangling Horizontal and Vertical Intra-Industry Trade WP Cepii, N²005-10 
Foresti Giovanni, Trenti Stefania (2006) Apertura delle filiere produttive: la nuova collocazione dell'industria italiana nello scenario internazionale, in Giuseppe Tattara, Giancarlo Corò , Mario Volpe (2006) Andarsene per continuare a crescere, pp. 87-112.

Gereffi Gary (2002) The international competitiveness of Asian economies in the apparel commodity chain, ERD working paper, n. 5.

Gereffi Gary, John Humphrey and Tim Sturgeon (2005) The Governance of Global Value Chain, Review of International Political Economy, 12 (1), pp. 78-104.

Gereffi, Gary (1993) The Organization of Buyer-Driven Global Commodity Chains: How U.S. Retailers Shape Overseas Production Networks, in Commodity Chains and Global Capitalism, by Gary Gereffi and Miguel Korzeniewicz (eds.), Greenwood Press, pp. 95-122.

Gianelle Carlo, Giuseppe Tattara (2008) Manufacturing abroad while making profits at home: Veneto footwear and clothing industry. In Mario Morroni (ed.) Corporate Governance, Organization and the Firm: Co-operation and Outsourcing in a Globalised Market. E.Elgar, M. Pitman. In press

Harrison Bennett (1994) Lean and Mean: Why Large Corporations Will Continue to Dominate the Global Economy, New York: Basic Books.

Kaminski Bartlomiej, Ng Francis (2000) Trade and Production Fragmentation: Central European Economies in EU Networks of Production and Marketing. World Bank Discussion Paper.

Lazerson Mark H., Lorenzoni Gianni (1999) The Firms that Feed Industrial Districts: A Return to the Italian Source. Industrial and Corporate Change, 8 (2), pp. 235-266.

Leamer, Edward E.; Storper, Michael (2001) The Economic Geography of the Internet Age." Coauthored with Edward Leamer, Journal of International Business Studies 32,4: Fourth Quarter, pp. 641-666.

Maggi Elena, Mariotti Ilaria and Boscacci Falvio (2007) The indirect effect of manufacturing internationalisation on logistics: evidence from the Italian districts, Univerità degli studi del Molise, Economics and statistics discussion paper n. 31/07.

Mariotti Ilaria, Micucci Giacinto, Montanaro Pasqualino (2004) Internationalisation strategies of Italian districts SMEs: an analysis on firl-level data. ERSA 436 published in Italian as Le forme dell'internazionalizzazione nei distretti industriali: un'analisi su microdati di impresa, in Carlo A. Bollino, Linda Diappi (eds.) Innovazioni metodologiche nelle scienze regionali, F. Angeli. Milano, pp. 177-199.

Menghinello Stefano (2004) Local engines of international trade: the case of industrial districts in Italy" in The Evolution of Local Capitalism in Italy. In Cainelli Giulio and Zoboli Roberto (eds.) Contribution to Economics, Physica Verlag, Heidelberg, pp. 317335.

Nasser Al-Mawali (2005) Disentangling Total Intra-Industry Trade into Horizontal and Vertical Elements. In Atlantic Economic Journal, v 33 (4),December, pp. 491-492. 
Nefussi Benjamin Schwellnus Cyrille (2007) Does FDI in Manufacturing Cause FDI in Business Services? Evidence from French Firm-Level Data, WP Cepii, Nº 2007-21

Piore, Michael, and Charles F. Sabel (1984) The Second Industrial Divide: Possibilities for Prosperity. New York: Basic Books.

Porter Michael E. Sakakibara Mariko (2000) Competing at home to win Abroad:

Evidence from Japanese Industry, The Review of Economics and Statistics, 83.2.may, pp. 310-322.

Porter Michael E., (1990) The Competitive Advantage of Nations New York: The Free Press, 1990.

Rabellotti Roberta (2006) Globalization, Industrial Districts and Value Chain, in Masatsugu Tsuji, Emanuele Giovannetti, Mitsuhiro Kagami (eds.), Industrial Agglomeration and New Technologies: A Global Perspective. Edward Elgar Publishing, pp. 225-245.

Rosenberg Nathan (1963a) Capital Goods, Technologyand Economic Growth, Oxford Economic Papers, 15(3) Nov. pp. 217-227. Rep. in Nathan Rosenberg, Perspectives on Technology,Cambridge Un. Press, Cambridge MA, 1976.

Rosenberg Nathan (1963b) Technological Change in the Machine Tool Industry: 18401910, Journal of economic history, 23(4) dec. pp. 414-443. Rep. in Nathan Rosenberg, Perspectives on Technology,Cambridge Un. Press, Cambridge MA, 1976.

Rossetti Stefania, Schiattarella Roberto (2003) Un approccio di sistema all'analisi della delocalizzazione internazionale. Uno studio per il settore del made inb Italy. In Nicola Acocella, Eugenio Sonnino (eds.), Movimenti di persone e movimenti di capitali in Europa. Il Mulino, Bologna, pp. 385-502.

Rugman Alan M. Verbeke Alain (2005) Multinational Enterprises and Clusters: An Organizing Framework. In Analysis of Multinational Strategic Management: The Selected Scientific Papers of Alan M. Rugman and Alain Verbeke, Cheltenham, U.K. and Northampton, Mass.: Elgar, pp. 251-269.

Russo Margherita (2006) Processi di innovazione nei distretti e globalizzazione: il caso si Sassuolo. In Giuseppe Tattara, Giancarlo Corò and Mario Volpe, Andarsene per continuare a crescere, pp. 281-308.

Schumpeter Joseph (1911) Theorie der wirtschaftlichen Entwicklung, 1911 - Leipzig, Duncker and Humblot, Engl. transl. The Theory of Economic Development: An inquiry into profits, capital, credit, interest and the business cycle. Harvard University Press, Cambridge MA, 1934

Tattara Giuseppe (2001) Il piccolo che nasce dal grande. Le molteplici facce dei distretti industriali Veneti. Franco Angeli. Milano.

Tattara Giuseppe, Corò Giancarlo, Volpe Mario (2006) Andarsene per continuare a crescere. La delocalizzazione internazionale come strategia competitiva. Carocci. Roma.

Thiel Joan, Pires Iva, Dudleston Anna (2000) Globalisaton and the Portuguese Textile and Clothing Filière inthe Post-Gatt Climate, in Anna Giunta Arnoud Langedijck, Andy Pike (eds.), Restructuring Industry and Territory: The Experience of Europe’s Regione. The Stationary Office (TSO), London, pp. 109-126. 
Yeats, Alexander J. (1998) Just How Big Is Global Production Sharing? Policy Research Working Paper 1871, The World Bank, Development Research Group, Washington D.C. January. 